\title{
KAJIAN STRUKTURAL-SEMIOTIK PADA KUMPULAN SAJAK LAGU PADUNGDUNG KARYA DENI AHMAD FAJAR UNTUK BAHAN PEMBELAJARAN MEMBACA SAJAK DI SMA
}

\author{
Arini Dwi Jayanti \\ MGMP Bahas Sunda Kabupaen Purwakarta \\ Pos-el: dwijayanti.arini@yahoo.co.id
}

\begin{abstract}
Abstrak
Latar belakang penelitian ini dikarenakan sajak masih berkembang di masyarakat, termasuk pelajar dan mahasiswa. Penelitian ini bertujuan untuk menganalisis teks-teks sajak yang terdapat dalam kumpulan sajak Lagu Padungdung karangan Deni Ahmad Fajar, untuk mendeskripsikan: (1) struktur sajak, (2) unsur semiotik sajak, dan (3) penerapan hasil penelitian terhadap bahan pembelajaran membaca sajak di SMA. Metode yang digunakan dalam penelitian ini adalah deskriptif-analitik dengan menggunakan tehnik studi pustaka dan analisis data, yakni mencari referensi yang dapat dijadikan landasan teori untuk mendeskripsikan hasil analisis. Instrumen penelitian yang digunakan adalah kartu data. Analisis struktural dalam sajak meliputi unsur tema, nada, rasa, dan amanat yang terdapat dalam struktur sajak, yang kemudian dipahami maknanya melalui analisis semiotik Charles Sander Peirce, yaitu ikon, indeks, dan simbol. Hasil pengolahan data struktural didapat tema, nada, rasa, dan amanat. Tema yang paling banyak yaitu, tema cinta dan kematian, nadanya nada menyindir dan sedih, rasanya menggambarkan rasa kerinduan, dan amanatnya lebih banyak mengingatkan pada pembaca. Hasil pengolahan semiotik didapat data unsur ikon ada 76, unsur indeks ada 140, dan unsur simbol ada 120. Secara keseluruhan dari hasil penelitian ini terdapat 30 sajak yang bisa direkomendasikan untuk bahan pembelajaran membaca sajak di SMA.
\end{abstract}

Kata kunci: sajak, struktural, semiotik, bahan pembelajaran membaca

\section{STRUCTURAL-SEMIOTIC ANALYSIS ON THE POEM ANTOLOGHY LAGU PADUNGDUNG BY DENI AHMAD FAJAR FOR TEACHING MATERIALS OF POEM READING IN SENIOR HIGHSCHOOL}

\begin{abstract}
This research is based on the ever-growing development in the community, including senior high school students and college students. The study aims to analyze poem texts from the poem anthology Lagu Padungdung by Deni Ahmad Fajar, to describe: (1) poem structure, (2) poem semiotic elements, and (3) the application of the result of the study on teaching poem reading in senior high school. The method used in the study is descriptive-analysis by conducting literature review and data analysis, namely searching available to be referredtheories as the foundation to describe the analysis results. The instrument used isdata cards. Structural analysis in poem covers theme, tone, feel, and moral valueof the poem, which are later interpreted through Charles Sander Peirce semiotic analysis, namelyicon, index, dan symbool. The result of structural data collections includes theme, tone, feel, and moral value. The most common themes are love and death, thetones are sarcasm and sorrow, the feel is yearning, and the moral value deals morewith making the readers to remember. The result of semiotic analysis is that thereare 76 icons, 140 indexes, and 120 symbols. Overall findings of this study is that there are approximately 30 poems
\end{abstract}


which can be recommended to be used asteaching materials of poem reading in senior high school.

Keywords: poem, structural, semiotic, teaching reading materials

\section{PENDAHULUAN}

Sastra merupakan alat untuk menyampaikan ide atau gagasan yang disampaikan dalam media tulisan. Begitu juga dengan pengertian karya sastra, karya sastra merupakan ide atau gagasan dari pengarangnya dalam mengolah bahasa melalui media tulisan yang mengandung unsur keindahan. Keindahan berbahasa tersebut berasal dari pemikiran yang menghasilkan serangkaian bahasa atau tulisan yang terasa menarik oleh pembacanya. Bahasa dalam sastra bisa berupa bahasa lisan yang menghasilkan sastra lisan, dan bahasa tulisan yang menghasilkan sastra tulis.

Berdasarkan bentuk karya sastra, sastra terbagi dalam tiga jenis, yaitu: puisi, prosa, dan cerita drama (Iskandarwassid, 2003, kc. 138). Karya sastra yang menjadi objek dalam penelitian ini yaitu dikhususkan pada bentuk sajak, karena sajak termasuk ke dalam salah satu jenis puisi.

Sajakyaitu karya sastra yang termasuk ke dalam sastra modern, merupakan salah satu jenis dari puisi Sunda, yang tidak terikat oleh aturan-aturannya. Oleh karena itu bisa juga disebut sajak bebas. Pengertian bebas dalam konteks tersebut artinya lebih relatif. Jika dibandingkan dengan guguritan yang ditulis dalam bentuk pupuh, sajak tentunya lebih terasa bebas. Tidak terikat oleh jumlah baris dalam satu baitnya, jumlah suku kata dalam satu baitnya, atau suara vokal terakhir dalam setiap baitnya. Jika dibandingkan dengan sisindiran, sajak tidak terikat oleh lampiran dan isi. Jika dibandingkan dengan mantra, sajak tidak terikat oleh pilihan kata yang mengandung kekuatan gaib, atau yang diucapkannya untuk tujuan-tujuan yang berhubungan dengan kepercayaan (Tamsyah, 1996, kc. 185).
Bahasa dalam sajak biasanya menggunakan pilihan kata yang padat dan bersifat konotatif. Dalam memahami makna suatu teks sajak dibutuhkan ketelitian, kecermatan dan daya imanjinasi yang kuat dari pembacanya. Agar pembaca bisa memahami maksud dan arti dari sajak yang dibacanya, maka sebelum memaknai sajak secara utuh, biasanya pembaca harus terlebih dulu mengenal unsur-unsur yang terdapat di dalam teks sajak secara implisit dengan cara menganalisis teks sajaknya. Ini merupakan analisis dengan tujuan untuk memahami struktur sajak

Struktur sajak yaitu bagian-bagian yang membangun suatu sajak. bagian tersebut membentuk sajak secara utuh. I.A. Richards (dalam Tarigan, 2011, kc. 9) menyatakan bahwa sajak mempunyai unsur makna seutuhnya. Pada hakikatnya sajak terdiri dari (1) tema (sense), (2) nada (tone), (3) rasa (feeling), dan (4) amanat (itention).

Perkembangan sajak dari waktu ke waktu mengalami berbagai perubahan, disebabkan oleh kemajuan ilmu pengetahuan, tekhnologi, dan nilai estetika dari pengarangnya. Sekarang ini karangan sastra kian diminati. Contohnya dengan diadakannya perlombaan-perlombaan mengenai sajak, acara-acara yang menampilkan kreasi sajak.Sajak kian diminati oleh semua lapisan masyarakat, baik oleh mahasiswa maupun oleh para pelajar di sekolah.

Data-data yang ditemukan mengenai kegiatan yang berhubungan dengna sajak, misalnya pada bulan April 2013 SMKN 2 Pasundan Kota Tasikmalaya menyelenggarakan perlombaan membaca sajak Sunda untuk siswa SD, SMP, dan SMA. Pada bulan April 2012 diadakan workshop bahasa dan sastra Sunda yang isinya membahas tentang sajak-sajak 
Sunda yang diprakarsai oleh Disparbud Provinsi Jawa Barat, dengan pemateri seperti Etty R.S., Godi Suwarna, Acep Zamzam Noor, Hawe Setiawan, dan Dian Hendrayana, ada pertunjukan rampak sajak, ada juga dalam bentuk yang paling baru yaitu kreasi sajak lewat musikalisasi sajak. Begitu juga dengan acara rutin yang diadakan oleh Jurusan Pendidikan Bahasa Daerah UPI dalam acara Riksa Budaya Sunda (RBS), yaitu perlombaan tentang sastra-sastra Sunda, termasuk perlombaan membaca sajak. Oleh karenaitu terbuktibahwa karya sastra dalam bentuk sajak semakin diminati. Sajak Sunda menjadi salah satu bentuk sastra Sunda dan diterima sebagai bagian dari ekspresi sastra Sunda dalam bahasa Sunda. Sesuai yang ada di sastra Indonesia, Pradopo (dalam Jabrohim, 2012, kc. 119), mengemukakan bahwa:

Puisi kian diminati oleh masyarakat, baik oleh pelajar, mahasiswa, maupun masyarakat pada umumnya. Akan tetapi puisi atau sajak sukar dimengerti karena kompleksitas, pemadatan, kiasan-kiasan, dan pemikirannya yang sukar.

Adanya kompleksitas cara memahami sajak, menyebabkan perlu adanya analisis sajak. Dalam menganalisis karya sastra tentu harus menggunakan salah satu teori sastra, dalam penelitian ini digunakan analisis struktural karangan sastra yang kemudian dipahami maknanya dengan analisis semiotik. Seperti yang dikemukakan oleh Pradopo (2007, kc. 118) bahwa strukturalisme tidak bisa dipisahkan dengan teori semiotik. Penelitian sastra menggunakan teori semiotik sebenarnya merupakan terusan dari teori strukturalisme.

Peirce (dalam Jabrohim, 2012, kc. 123) semiotik (semiotika) yaitu ilmu yang membahas mengenai tanda. Ilmu ini menganggap bahwa kejadian di masyarakat itu merupakan tanda-tanda. Semiotik membahas sistem-sistem, aturan-aturan, dan konvensi-konvensinya. Tanda-tanda tersebut mempunyai arti dan makna, yang ditentukan oleh konvensinya. Karya sastra merupakan struktur tanda-tanda yang mempunyai makna. Teori semiotik Peirce terdiri atas tanda ikon, indeks, dan simbol.

Tahun 2012 terbit buku kumpulan sajak Lagu Padungdung (LP), buku tersebut terpilih untuk mendapatkan hadiah Sastra Rancage 2013, serta mempunyai nilai sastra yang baik. Dari indikator tersebut, peneliti menganalisis buku tersebut. Oleh karena itu, objek dalam penelitian ini yaitu kumulan sajak LP karangan Deni Ahmad Fajar, hasil penelitian diterapkan pada bahan pembelajaran membaca sajak di SMA. Dalam kurikulum 2013, pembelajaran mengenai sajak ada di SMA kelas XI. Isi dari kumpulan sajak $L P$ tersebut bisa menarik minat siswa karena tema-tema sajaknya menceritakan tema-tema yang ada di sekitar lingkungan sosial siswa. Hal tersebut sesuai dengan yang dikatakan Suherman (2015) bahwa beberapa sajak dalam $L P$ dapat dijadikan alternatif bahan pembelajaran.

Berdasarkan pembahasan sebelumnya, penelitian ini mempunyai tujuan untuk mengidentifikasi dan mendeskripsikan unsur-unsur struktural, unsur-unsur semiotik sajak dalam buku kumpulan sajak $L P$, serta menerapkan hasil penelitian pada materi pembelajaran membaca sajak di SMA.

\section{METODE}

Metode yang digunakan dalam penelitian ini yaitu metode deskriptifanalitik. Metode deskriptif analitik dilaksanakan dengan cara mendeskripsikan fakta-fakta atau data-data yang seterusnya disusul dengan analisis (Ratna, 2013, kc. 53).Sumber data dalam penelitian ini yaitu semua teks sajak yang terdapat dalam buku kumpulan sajak LP karangan Deni Ahmad Fajar, menggunakan teori strukturalsemiotik. 
Desain atau langkah-langkah dalam penelitian ini yaitu (1) identifikasi masalah, (2) merumuskan dan membatasi masalah, (3) menentukan teori, mengumpulkandata (5) mengolah dan menganalisis data, (6) membuat kesimpulan dari hasil analisis data, dan (7) menyusun laporan.

Instrumen yang digunakan dalam penelitian ini yaitu menggunakan kartu data, guna menganalisis struktur dan semiotiknya.

Setiap data yang ditemukan dalam kumpulan sajak LP diberi kode tertentu, contoh kode, misalnya sajak Kalangkang II (11.13.03).

Keterangan: $\quad 11=$ nomor urut sajak

$$
\begin{aligned}
& 13=\text { halaman } \\
& 03=\text { baris }
\end{aligned}
$$

\section{HASIL DAN PEMBAHASAN}

Kumpulan sajak LP merupakan kumpulan sajak Sunda, terbit tahun 2012 yang mendapatkan hadiah Sastra Rancage tahun 2013 serta mempunyai nilai bahasa yang baik. Dalam sajak ini dianalisis menggunakan teori struktural dan semiotik serta penerapannya pada materi pembelajaran membaca sajak di SMA. Teoriyang digunakan dalam penelitian yaitu teori I.A. Richard untuk menganalisis struktural dan teori Peirce untuk menganalisis unsur semiotiknya.

Pertama, dalam teori struktural dianalisis unsur tema, nada, rasa, dan amanat, berdasarkan pada teks-teks sajaknya. Lebih jelasnya akan dijelaskan seperti di bawah ini.

\section{1) Tema}

Tema sajak yang didapat dari hasil analisis yaitu tema kematian jumlahnya ada lima sajak ("Réquim", "Obituari II", "Introspéksi Tungtung Taun", "Introspéksi ti rumentang Siang", dan "Kalangkang III").

Tema cinta ada sepuluh sajak ("Aya anu Ngali Kuburan", "Dina Harina", "Kalangkang II", "Ayun Ambing Panineungan", "Legénda", "Obituari",
"Lagu Gandrung", "Bayah: Hiji Catetan", "Ngabungbang", dan "Bangkarak Panineungan").

Tema keagamaan ada empat sajak ("Linglung", "Sajak Heureuy", "Hirup", jeung "Tol").

Tema keadaan sosial ada lima sajak ("Parodi", "Bandung", "Tol II", "Panggih jeung sobat", dan "Ngabungbang II").

Tema mengenai kehidupan atau hakikat diri ada lima sajak ("Sisiphus", "Kalangkang", "Lagu Padungdung", "Panto", dan "Introspéksi Satsion Rangkasbitung"). Terakhir didapat tema tentang perpisahan ada dua sajak (“Milangkala" dan Milangkala II")

\section{2) Nada}

Nada yang didapat dari kumpulan sajak LP yaitu nada sengsara, nada penasaran, nada yang penuh ketenangan, nada gelisah, nada menyindir, pasrah, menantang, rindu, takut, menyesal, bersemangat, sepi, bingung, menggurui, dan nada marah.

\section{3) Rasa}

Rasa yang didapat dari kumpulan sajak $L P$ yaitu rasa sedih, gelisah, rindu, prihatin, tenang, sinis, senang, pasrah, sombong, tak tentu arah, dan rasa kesal.

\section{4) Amanat}

Amanat yang terdapat dalam setiap sajaknya kebanyakan pengarang mengingatkan kepada pembaca bagaimana dekatnya kematian dengan kita, pengarang memberi nasihat bahwa dalam menjalani kehidupan haruslah disertai dengan kesabaran, pengarang mengingatkan kepada pembaca bagaimana keadaan Bandung sekarang ini, pengarang mengingatkan mengenai hakikat diri, siapa diri kita sebenarnya dan siapa Tuhan yang telah menciptakan kita?

Contoh analisis struktural sajak diterangkan dalam contoh tiga teks sajak, 
yang berjudul "Réquim”, "Aya anu Ngali Kuburan", dan sajak "Dina Harina" seperti dijelaskan di bahwah ini.

\section{Teks Sajak Nomor 01 (01.01) REQUIM}

geus laas kecap-kecap pikeun ngawangun anjeun,

langit soré digurat saabringan manuknu nyieun silhuét

peuting. dahan-dahan haté ngarandakah dahan-dahan simpé

teuing $\mathrm{ku}$ tengeles ari waktu, ninggalkeun kalangkang

beurang. aya anu ngajerit leungiteun cahaya matapoé.

girimis ngamimitian hujan di pajaratan. hiji catetan

keur urang: panineungan horéng kuburan!

\section{a) Parafrase}

Requim dalam Kamus Bahasa Inggris (2010, kc. 479), artinya lagu kematian. Dari judul sajaknya saja sudah tergambar bagaimana temanya dan menceritakan tentang apa. Sajak "Requim" bertema kematian, yang isinya menceritakan bagaimana tandatanda seseorang yang sudah mendekati ajalnya, menggambarkan secara implisit bagaimana sedihnya orang yang harus ditinggal mati, dengan tanda-tanda hati tidak tenang, pikiran kacau, muncul semacam bayanganbayangan hitam, dan dalam sajak tersebut disebutkan langit sore hari yang menandakan umur yang sudah semakin menua. Pengarang mengingatkan kepada pembaca bahwa tempat berpulang yang abadi dilambangkan dengan adanya kuburan. Gambaran yang memisahkan dua dunia yang berbeda, dunia dan akhirat. Alam manusia dan alam yang tidak bisa dipikirkan dengan logika.

\section{b) Tema}

Tema yang didapat dari sajak ini seperti yang telah digambarkan pada parafrase di atas yaitu tema mengenai kematian. Hal itu tergambar dari baris keempat sampai baris ketujuh, seperti di bawah ini.

teuing $k u$ telenges ari waktu, ninggalkeun kalangkang

beurang. aya nu ngajerit leungiteun cahaya matapoé

girimis ngamimitian hujan di pajaratan. hiji catetan

keur urang: panineungan horéng kuburan!

Dalam baris keempat ada kata meninggalkan, dalam baris kelima ada konteks leungiteun cahaya matapoé, dan dalam baris keenam dan ketujuh lebih eksplisit yang ditandai dengan kata pajaratan dan kuburan. Baik kata ninggalkeun, kuburan, pajaratan, itu semua yang menjadi indikator tema kematian.

c) Nada

Nada yang didapat dari sajak "Requim" yaitu nada sengsara. Pengarang ingin menyampaikan bagaimana sedihnya orang yang ditinggal mati dan bagaimana gelisahnya seseorang yang sudah mendekati ajalnya. Hal itu bisa tergambar pada konteks di bawah ini.

dahan-dahan haté ngarandakah dahan-dahan simpé

teuing $k u$ telenges ari waktu, ninggalkeun kalangkang

beurang. aya nu ngajerit leungiteun cahaya matapoé girimis ngaimitian hujan di pajaratan

\section{d) Rasa}

Rasa yang didapat dari sajak tersebut yaitu rasa sedih dan gelisah. Rasa sedih ditinggal mati oleh orang yang dicintai. Rasa sedih tergambar 
pada baris kelima dan keenam. Dalam baris "aya nu ngajerit leungiteun cahaya matapoé. girimis ngamimitian hujan di pajaratan",dan rasa gelisah tergambar pada baris ketiga, "dahandahan haté ngarandakah dahandahan simpé”.

\section{e) Amanat}

Amanat yang ingin disampaikan oleh pengarang dalam sajak "Requim" yaitu mengingatkan kepada pembaca bahwa kehidupan ini tidak abadi. Kematian merupakan takdir Tuhan yang tidak bisa dihindari, air mata menandakan rasa sedih. Kuburan merupakan simbol yang memisahkan dunia dan akhirat yang berarti perpisahan untuk selama-lamanya. Kuburan menjadi simbol tempat yang bisa dikenang oleh orang yang masih hidup kepada orang yang sudah meninggal. Hal ini tergambar pada baris terakhir "panineungan horeng kuburan!"

\section{Teks Sajak nomor 02}

\section{(02.02) AYA ANU NGALI KUBURAN}

aya anu ngali kuburan dina mata anjeun

:kuring jeung panineungan!

\section{a) Parafrase}

Pengarang dalam sajak "Aya Anu Ngali Kuburan" menceritakan pasangan yang sedang dilanda kebingungan. Dalam baris pertama, pengarang, menggambarkan dengan istilah mata dari panca indera untuk mengartikan hal-hal yang bisa dilihat. Yang dikaitkan dengan istilah mata adalah jendelanya hati. Pengarang menatap kekasihnya, menatap matanya lalu tergambar ada yang sedang menggali kuburan, mengubur dirinya dengan berbagai kenangan mereka. Kuburan mempunyai arti ada yang dikubur, segala sesuatu yang sudah dikubur, tentu akan berbeda alam. Konteks "aya anu ngali kuburan..." dalam sajak tersebut bisa diartikan bahwa pasangan itu sedang mengalami permasalahan dalam hubungan mereka. Ada yang terlihat ikhlas, siap untuk melupakan tergambar dari matanya, yang terlihat ada yang sedang menggali kuburan, untuk semua kenangan. Tapi pasangannya berada dalam keadaan sebaliknya, ia terlihat dalam keadaan gelisah dan ada rasa tidak bisa menerima keadaan.

\section{b) Tema}

Sajak "Aya Anu Ngali Kuburan" temanya yaitu tema cinta. Cinta yang harus bertemu dengan perpisahan. Kuburan menggambarkan batas antara yang hidup dan yang sudah meninggal. Jika sudah terpisahkan oleh kuburan tentunya tidak akan bisa untuk bersatu lagi. Kuburan merupakan simbol perpisahan yang tidak bisa ditawar lagi dengan kata rujuk. Cerita cinta tidak selalu berakhir bahagia, ada juga cerita cinta yang harus merasakan pahitnya asmara, seperti yang digambarkan dalam teks sajak di bawah ini.

aya anu ngali kuburan dina mata anjeun

:kuring jeung panineungan!

\section{c) Nada}

Nada yang didapat dari sajak tersebut yaitu nada yang membuat penasaran dari pembacanya. Pengarang menyampaikan sajaknya dalam nada yang menimbulkan berbagai pertanyaan dari pembacanya, pertanyaan siapa yang menggali kuburan itu, saya? Kenangan saya? Atau siapa? Hingga membuat pembaca menafsirkan beberapa kemungkinan, yang digambarkan dalam sajaknya "aya anu ngali kuburan", siapa yang sedang menggali kuburan itu? Untuk apa menggali kuburan? Setelah membaca sajak tersebut, pembaca tentunya akan menimbulkan pertanyaan-pertanyaan seperti itu. 


\section{d) Rasa}

Sajak "Aya Anu Ngali Kuburan" menggambarkan rasa gelisah. Pengarang menggambarkan bagaimana gelisahnya perasaan Si Kuring, harus melihat ada yang sedang menggali kuburan atas persoalan yang sedang dihadapi bersama pasangannya. Seakan sudah tidak menemukan lagi titik terang untuk jalan keluar akan persoalannya. Ada rasa takut, takut cerita cintanya harus berakhir, hal ini tergambar pada baris kedua ":kuring jeung panineungan."

\section{e) Amanat}

Amanat yang ingin disampaikan pengarang melalui sajak "Aya Anu Ngali Kuburan" yaitu mengingatkan kepada pembaca bahwa dalam cerita cinta tidak semua berakhir manis, tidak selamanya bahagia. Ada waktunya persoalan cinta dihadapkan dengan kenyataan yang menyedihkan, misalnya kematian. Setelah ada dalam kenyataan kematian, manusia hanya bisa pasrah dengan tempat terakhirnya yaitu dimasukan ke liang lahat. Ada cerita yang sedih, membawa sengsara dan luka. Oleh sebab itu pesan yang ingin disampaikan pengarang yaitu mengingatkan bahwa sifat ikhlas itu harus selalu menyertai setiap cerita kehidupan kita.

\section{Teks Sajak Nomor 03}

\section{(03.03) DINA HARINA}

ningali cika-cika tina karéta

bet aya teuteup anjeun dina kaca jandéla

ngajorélat sapanjang lanskap

mongkléng

ningali cika-cika dina karéta

sanggeus anjeun ngajorélat jadi panineungan

simpé ngembat sapanjang léngkah nyorangan! a) Parafrase

Harina merupakan nama dari sebuah kereta api kelas eksekutif dan bisnis dengan rute statsion Surabaya Pasarturi sampai ke statsion Bandung. Dari teks sajak "Harina" tergambar bahwa ketika membuat sajaknya, pengarang sedang berada di dalam kereta tersebut, yaitu kereta Harina. Dengan latar waktu malam, dalam keadaan sendiri. Tergambar pada baris ketiga "ngajorélat sapanjang lanskap mongkléng"dan pada baris keenam "simpé ngembat sapanjang léngkah nyorangan!" pengarang melihat pemandangan dari kaca jendela kereta dan yang terlihat hanyalah gelap. Ketika dengan tenangnya melihat keadaan yang ada di luar, perhatian pengarang terfokus pada kunangkunang yang ada di luar kereta, terlihat dari gelapnya suasana malam. Sepintas serasa ada bayangan dia datang seraya menatapnya, yang terlihat dari kaca jendela. Tapi hanya sekejap, lalu menghilang kembali. Dia yang telah menjadi kenangan. Bayangannya datang dan menghilang seketika, tapi pengarang hanya bisa melanjutkan perjalanannya sendiri dalam kereta bertemankan sepi. Tanda-tanda tersebut menggambarkan cerita pengarang dengan kenangannya yang hanya sekejap, tergambar dari katakata cika-cika, mongkléng, sajorélat, karéta, dan panineungan. Cika-cika (kunang-kunang) merupakan hewan kecil yang bisa menyala dalam keadaan gelap, cahayanya hanya sebentar ketika ada dalam keadaan gelap saja, yang ada hubungannya dengan kata sajorélat, kata sajorélat diartikan waktu yang hanya sebentar. Begitu juga dengan lajunya kereta yang dengan begitu cepat, hanya sekejap. Lalu semua yang pernah ada hanya sebentar dan semuanya akan jadi kenangan, tentang kejadian yang pernah dialami. 


\section{b) Tema}

Tema yang didapat dari sajak "Dina Harina" yaitu tema cinta, dalamsajak tersebut digambarkan bagaimana kunang-kuanng yang membangkitkan kenangan kepada seseorang yang pernah jadi kekasih pengarang, sayangnya cerita cintanya tak berlangsung lama, hanya sekejap sama halnya seperti bayang-bayang yang datang saat pengarang berada di dalam kereta, malam itu. Tidak disengaja teringat dan terbayang, Si dia yang sudah menjadi kenangan. Hal itu tergambar pada baris di bawah ini.

ningali cika-cika dina karéta

sanggeus anjeun ngajorélat jadi panineungan

simpé ngembat sapanjang léngkah nyorangan!

\section{c) Nada}

Nada dalam sajak"Dina Harina" menggambarkan nada tenang. Tenang dalam menggahadapi kenangankenangan yang sudah dialami. Meskipun teringat kembali tapi tidak membuat suasana kacau dan sedih. Pengarang menggambarkan sikap ikhlas dalam menjalani rangkaian cerita kehidupannya dan terus bergulir untuk menyambut massa yang akan datang. Hal itu tergambar dari baris terakhir, seperti di bawah ini.

sanggeus anjeun ngjorélat jadi panineungan

simpé ngembat sapanjang léngkah nyorangan!

\section{d) Rasa}

Rasa yang didapat dari sajak
tersebut yaitu rasa kerinduan
pengarang kepada kekasih hatinya,
yang tak diduga akan teringat kembali
dalam bayang-bayang yang datang
malam itu, lewat bayang-bayang yang
didatangkan oleh kunang-kunang.
Sendiri dan merasa sepi, waktu malam
di dalam kereta. Dalam suasana seperti
itu biasanya segala sesuatu pasti terkenang kembali, khususnya hal-hal yang tidak bisa dilupakan. Hal ini tergambar pada baris ketiga "ngajorélat sapanjang lanskap mongkléng" jeung padalisan kalima "sanggeus anjeun ngajorélat jadi panineungan”.

\section{e) Amanat}

Amanat yang ingin disampaikan pengarang dalam sajak "Dina Harina" yaitu ada hal-hal yang harus dikejar diwaktu mendatang dan ada juga yang hanya cukup untuk dikenang, guna dijadikan pembelajaran ke depannya. Setiap manusia tentu mempunyai kenangan yang menjadi guru kehidupan. Dalam sajak tersebut digambarkan yang menjadi khayalannya yaitu cerita yang membangkitkan rasa sedih, rasa sedih yang tergambar dalam kata sajorélat,panineungan, dan nyorangan. meskipun dalam keadaan sedih, tapi kehidupan tidak boleh terhenti oleh kenangan, kehidupan harus terus berjalan, seperti laju kereta yang terus melaju dan berhenti saat waktunya tiba.

Kedua, dalam teori semiotik yang dianalisis terdiri dari ikon, indeks, dan simbol, yang tujuannya untuk memahami makna sajak. Contoh analisis sajak diterangkan seperti di bawah ini.

\section{Analisis Unsur Ikon}

Dalam kode 01.01.3 "ninggalkeun kalangkang" dalam konteks tersebut kata kalangkang mempunyai ari bentuk yang menyerupai raga kita. Dalam kode 03.03.5, "sanggeus anjeun ngajorélat jadi panineungan”, dalam konteks tersebut kata anjeun mempunyai arti gambaran yang dimaksudkan pada kekasih hatinya. Dalam kode 12.14.5 (sajak "Ayun Ambing Panineungan") ada kata "anjeun", kataanjeundalam konteks sajaktersebut merupakan gambaran 
untuk seseorang yang sedang ditunggu-tunggu. Dalam kode 17.20.5, "kamana nyusul tapak anjeun?", dalam konteks tersebuttapak anjeunmempunyai arti gambaran dari kematian. Dalam kode 20.23.8 "horéng anjeun geus waktuna nagih jangji: pati!", kataanjeundalam konteks tersebut merupakan gambaran waktu datangnya ajal. Dalam kode 24.28.4 "siga nu teu apal ka nu gareulis", dalam konteks tersebut katageulismerupakan gambaran persamaan dengan sifat wanita.

\section{Analisis Unsur Indeks}

Dalam kode 01.01.5 "aya nu ngajerit leungiteun cahaya matapoé" dalam konteks sajak tersebut merupakan indeksikal dari keadaan seseorang yang sedang bersedih karena ditinggal mati oleh orang yang dicintainya. Dalam kode 12.14.1-2 "digupay muara panineungan. Lagu ayun ambing ngagalura jeo dada", dalam konteks tersebut merupakan indeksikal dari keadaan yang sedang merasa rindu, karena sudah tidak sabar menanti kehadiran seseorang yang ditunggu-tunggunya. Dalam kode 17.20.1-3 "bongan pasini jeung waktu. urang paturay muru simpéna simpé. padahal can réngsé nyatet impian peuting tadi", dalam konteks tersebut merupakan gambaran waktu yang sudah mendekati ajalnya, dan menggambarkan bahwa waktu hidup di dunia ini tidak abadi. Dalam kode 19.22.1 "aya bulan langit cangra. mapay-mapay tapak anjeun"dalam konteks sajak tersebut merupakan indeksikal dari keadaan yang sedang merasa rindu, sampai-sampai menyusuri jalan setapak hanya untuk mencari bayang-bayang orang yang dirindukannya.

\section{Analisis Unsur simbol}

Dalam kode 31.37.4 "simpé: tempat urang paturay di pajaratan!" dlaam konteks sajak tersebut, kata pajaratan merupakan simbol yang menggambarkan rasa putus asa, karena cintanya ditolak oleh orang yang ia sayangi. Dalam kode 06.07.3 "sapanjang néangan masjid" dalam konteks ini, katamasjidmerupakan simbol dalammencari kebenaran yang hakiki akan Tuhannya. Dalam kode 14.16.2 "meulah sawah bapa" dalam konteks tersebut, katasawah merupakan simbol dari harta benda atau pekerjaan seseorang. Dalam kode 24.28.2 "paingan awak beuki ipis" dina éta kontéks, kataipismerupakan simbol yangmenggambarkan kehidupan yang penuh dengan penderitaan, sengsara, dan serba kekurangan. Jauh darikata senang karena tak punya uang sampai badannya tak bisa gemuk.

Hasil analisis unsur semiotik Charles Shander Peirce didapat 76 unsur ikon (di antaranya dalam konteks: ("anjeun", "silhuét", "kalangkang", "urang", "kuburan", "lanskap", "masjid", "cikacika", "alun-alun", "jalan dalem kaum", "cikapundung", "masjid agung”, "carita buhun”, "kalangkang urang”, "tapak anjeun", "sora adan", "basisir", "awak”, "geulis", "mata anjeun”, "kalangkang kuring”, jeung "kalangkang raga”). 140 unsur indeks (di antaranya dalam konteks: "aya nu ngajerit leungiteun cahaya matapoé”, "sanggeus anjeun ngajorélat jadi panineungan". "Simpé ngembat sapanjang léngkah nyorangan!" "Bongan pasini jeung waktu”. "Urang paturay muru simpéna simpé”, "aya gupay ronggéngronggéng nangtang makalangan" "tempokaula ayeuna geus jadi konglomerat". "hirup lugina jauh ti malarat", "basisir nu motah sapanjang lalampahan teuing $k a$ mana", "jadi bangkarak basa anjeun nundung kuring”, dsb.),dan ada 120 unsur simbol (di 
antaranya dalamkonteks: "langit soré", "peuting", "beurang", "cahaya matapoé”, "pajaratan", "kuburan", "mongkléng”, "simpé”, "masjid agung", "alun-alun", "eureun dina waktuNa", "si kabayan", "lagu ayun ambing", "jalan tol ngembat", "citarum", "lalakon", "palastra", "pasini", "bulan samagaha", "pileuleuyan”, "matapoé”, "lagu hirup”, "tarung”, "bulan langit cangra”, "katiga, si guha rasa", "waruga ngababatang", "haropak", "lekasan", "carita-carita buhun", "halabhab”, "nunggelis", "hirup lugina", "bulanngambang di langit simpé", "arulin oray-orayan", "linglung”, "nyorangan", "tetengger", jeung "bangkarak").

Penelitian ini dilarapkan pada bahan pembelajaran membaca sajak di SMA. Contohnya dengan menerapkan salah satu sajak yang berjudul sajak "Bandung". Sajak ini dibahas bersama-sama oleh guru dan murid-muridnya dalam proses belajarmengajar di kelas. Agar siswa dapat memahami isi teks sajak yang diterangkan oleh gurunya, tentunya proses pembelajarannya harus baik. Setelah diterangkan siswa diberi beberapa soal untuk dianalisis berdasarkan sajak yang diterangkan. Langkah terakhir, siswa membacakan sajak tersebut di depan teman-temannya. Melalui cara ini, akan terlihat kemampuan siswa dalam membaca sajak.

\section{SIMPULAN}

Berdasarkan hasil penelitian dan analisis sajak pada kumpulan sajak LP karangan Deni Ahmad Fajar sebagai Bahan Pembelajaran Membaca di SMA, dapat ditarik kesimpulan seperti berikut ini.

Kumpulan sajakLP, yang isinya ada 31 sajak. Sajak yang ke-31 itu dianalisis berdasarkan teori struktur sajak yang terdiri atas: (1) tema, (2) nada, (3) rasa, dan (4) amanat, yang seterusnya disusul dengan teori semiotik Charles Shander Peirce, yaitu ikon, indeks, dan simbol.

Tema sajak yang didapat dari sajakLP yaitu tema kematian didapat lima sajak, tema keagamaan ada empat sajak, tema cinta ada sepuluh sajak, tema keadaan sosial ada lima sajak, tema mengenai kehidupan atau hakikat diri ada lima sajak, dan tema perpisahan ada dua sajak. nada yang didapat dari sajakLP yaitu nada sengsara, nada penasaran, nada tenang, nada menyindir, nada pasrah, nada menantang, nada rindu, nada takut, nada menyesal, nada bersemangat, nada sepi, nada bingung, nada menggurui, dan nada marah. Rasa sajak yang didapat yaitu rasa sedih, rasa khawatir, rasa rindu, rasa prihatin, rasa tenang, rasa sinis, rasa senang, rasa pasrah, rasa sombong, dan rasa kesal. Amanat yang didapat kebanyakan hanya mengingatkan kepada pembaca, memberi gambaran mengenai keadaan sosial, dan mengingatkan tentang kematian.

Hasil analisis semiotik didapat ada 76 unsur ikon, 140 unsur indeks, dan 120 unsur simbol. Dalam penelitian ini unsur semiotik yang paling banayak ada pada unsur indeks, tanda semiotik yang ditandai dengan adanya hubungan sebab-akibat. Sedangkan tanda yang paling sedikit yaitu tanda ikon, yang memberi tanda kemiripan.

Dalam kumpulan sajakLP, ada 30 sajak yang memenuhi kriteria bahan pembelajaran membaca sajak di SMA, sedangkan yang tidak memenuhi kriteria ada satu sajak yang berjudul "Sisiphus", karena jauh dari latar belakang budaya dan pengetahuan siswa SMA.

\section{DAFTAR PUSTAKA}

Echols, J.M. \& Shadily, H. (2010). Kamus Inggris Indonesia (An EnglishIndonesia Dictionary). Jakarta: Gramedia Pustaka Utama.

Iskandarwassid. (2003). Kamus Istilah Sastra Pangdeudeul Pangajaran SastraSunda. Bandung: Geger Sunten.

Jabrohim. (2012). Teori Penelitian Sastra. Yogyakarta: Pustaka Pelajar. 
Pradopo, R. Dj. (2007). Pengkajian Puisi. Yogyakarta: Gadjah Mada University Press.

Ratna, Ny. Kh. (2013). Teori, Metode, dan Tehnik PenelitianSastra.Yogyakarta: Pustaka Pelajar.

Suherman, A. (2015). Padungdung nepi ka Padung. Mangle No. 1812.

Tamsyah, B.R. Spk. (1996). Pangajaran Sastra Sunda. Bandung: Pustaka Setia.
Tarigan, H.G. (2011). Prinsip-prinsip Dasar Sastra. Bandung: Angkasa.

\section{UCAPAN TERIMA KASIH}

Terima kasih kepada pengelola jurnal Lokabasa yang telah menerbitkan tulisan ini. Semoga tulisan ini ada manfaatnya bagi perkembangan ilmu pengetahuan. 